\title{
IT'S NOT JUST A PAY GAP: QUANTIFYING THE GENDER WAGE AND PENSION GAP AT A POST-SECONDARY INSTITUTION IN CANADA
}

\author{
TRACY SMITH-CARRIER \\ KING'S UNIVERSITY COLLEGE \\ AARON L. CECALA \\ WESTERN UNIVERSITY
}

\author{
MARCIE PENNER \\ KING'S UNIVERSITY COLLEGE \\ CAROL AGÓCS \\ WESTERN UNIVERSITY
}

\section{Abstract}

What is the impact of the gender pay gap in academia over the course of a career and retirement? To quantify this impact, we used a Canadian post-secondary institution as a case study and simulated the effects of the reported difference in salary across multiple academic career trajectories. A starting wage gap of less than $\$ 9,000$ resulted in a $\$ 300,000-\$ 400,000$ gender wage gap over the course of a career, and a further $\$ 148,000-\$ 259,000$ gender pension gap, for a total gender pension and wage gap of $\$ 454,000-\$ 660,000$, depending on the rank achieved. Thus, focusing on gender gaps in salary alone leads to a substantial underestimation of the long-term effects of the gender gap.

Keywords: gender equity, pay anomaly, salary anomaly, pension contributions, universities, faculty salaries

\section{Résumé}

Quel est l'impact de l'écart salarial entre les hommes et les femmes en milieu universitaire au cours d'une carrière et à la retraite? Pour quantifier cet impact, nous avons réalisé une étude de cas sur un établissement d'enseignement supérieur canadien et avons simulé les effets de la différence déclarée de salaire à travers de multiples trajectoires de carrière à l'université. Un écart salarial initial de moins de 9000 \$ a ainsi engendré un écart salarial entre les sexes de 300000 \$ à 400 000 \$ au cours d'une carrière ainsi qu'un écart de 148000 \$ à 259000 \$à la retraite, pour un écart total de $454000 \$$ à 660 $000 \$$ entre les sexes pour le salaire et la retraite combinés, selon le rang atteint. Ainsi, la considération des écarts entre les sexes sur la base du salaire seulement mène à une sous-estimation substantielle des effets à long terme de la disparité entre les sexes.

Mots-clés : égalité des sexes, anomalie de paie, anomalie salariale, cotisations de retraite, universités, salaires des professeurs et professeures

\section{Introduction}

Despite recent movements to rectify the prevailing gender wage gap, men consistently make more money than women for the same work, a pervasive problem that spans professions and specializations. Although a number of universities have made strides toward closing the gap in their respective institutions (e.g., at the University of Manitoba; see Shirle, 2019), more work is needed to not only eliminate such disparities but to address the consequences of such differences over time. Although ample literature documents the substantial gender wage gaps in Canadian universities (e.g., Canadian Association of University Teachers [CAUT], 2018; Doucet et al., 2012; Gatto et al., 2018; Momani et al., 2019), as has research in institutions elsewhere (e.g., Currie \& Hill, 2013), few have researched the extent to which such gaps impact professors' pension benefits over the life 
course. The purpose of this study is to not only examine the long-term effects of the gender pay gap, but also differences in pension earnings by gender, using a case study of a Canadian post-secondary institution.

\section{Background}

In 2018, in Canada, women employees between the ages of 25 and 54 earned $\$ 4.13$ less than their male counterparts per hour; meaning that for every dollar earned by men that year, women earned $\$ 0.87$. This translated in 2018 into an average real hourly wage rate of $\$ 26.92$ for women and $\$ 31.05$ for men (employees aged 25 to 54), a 13.3\% difference based on gender (Pelletier et al., 2019). Data from 2017 indicate that men made on average $\$ 59,200$, while women made $\$ 40,600$; a difference of $\$ 18,600$ (alternatively, the median salary in 2017 was $\$ 33,400$ for women and $\$ 47,500$ for men; a difference of $\$ 14,100)$. Although, on the whole, the wage gap between men and women has narrowed over the years, women continue to earn less money than men despite having higher levels of educational attainment (Moyser, 2019). Nascent research emerging since the onset of the COVID-19 pandemic suggests, however, that the health crisis may in fact be exacerbating existing gender inequalities, including gender pay gaps, specifically among parents of school-aged children (Qian \& Fuller, 2020).

In Canadian publicly assisted universities, the gender wage gap doggedly persists, irrespective of the measures employed to meaningfully tackle it. CAUT (2018) found that full-time women professors, who accounted for $44 \%$ of the professoriate in 2015 , earned $10 \%$ less than what men earned; the gap is larger still, at $17.5 \%$, when part-time staff are also considered (i.e., $\$ 110,713$ in average earnings for university instructors who were men relative to $\$ 91,366$ for women). Disparities exist not only along gender lines, but also along those of race and ethnicity (Li, 2012). The gap is deepest for racialized women, who earned only $\$ 0.68$ on the dollar (a difference of $32 \%$ ) relative to the dominant group (non-racialized, non-Indigenous men), according to the most recent census data (CAUT, 2018). In terms of senior academic administrators, Mang (2019) found that the wage gap is not only attuned to gender, but also to profession or discipline, with those in the health sciences, law, and social work earning between 12 to $33 \%$ more than administrators specializing in liberal fields in the social sciences and humanities.

Notwithstanding the corpus of research that has accumulated on the gender wage gap in universities over decades, the implications of this gap continue to be substantially underestimated. Few available studies have estimated the differences in pensionable earnings as a consequence of the gender pay disparities, particularly in institutions of higher education. One such study conducted in the early 1990s by Pesando and colleagues (1991) looked at gender pay differentials in defined benefit plans.

\section{Canadian Retirement Income System}

The Canadian retirement income system consists of three pillars: basic minimum programs, social insurance programs, and private and occupational plans. Given that this system was established on a male-breadwinner model (Marier \& Skinner, 2008), the income supports available to women, for most programs under these pillars, are lower relative to those for men. Indeed, Shilton (2013) suggests that women live on only two-thirds of what men typically enjoy at retirement. The deficiencies of the Canadian retirement income system, as Gazso (2005) points out, have led to significant financial insecurity for older women, particularly those without a male partner.

Despite having a multi-pronged retirement income system that provides various sources of income triggered at retirement (normally age 65), many of these pension programs provide less access to or lower benefits for women. Two of the key programs under the basic minimum pillar include Old Age Security (OAS) and the Guaranteed Income Supplement (GIS). OAS, adopted in 1952, was founded on a demogrant model, in that it was intended to provide a flat rate amount to all Canadian citizens (with few exceptions, outside strict residency requirements). In 1989, clawbacks were introduced in OAS based on income such that high-income earners see a gradual reduction in their OAS benefit once their income exceeds defined thresholds (i.e., in 2020, \$79,054) until the benefit is clawed back in full (i.e., in 2020, $\$ 128,149$; Government of Canada, 2020a, 2020b). For women professors, a 25-year career in academia would likely result in varying levels of access to OAS, and likely no income support available through the GIS, given that this basic income program is specifically for older adults living with low incomes. 
The second pillar of the Canadian retirement income system is built on an insurance model, dubbed the Canada Pension Plan (or Quebec Pension Plan; CPP/QPP). CPP/QPP provides a monthly taxable benefit for individuals who have been employed and contributed a portion of their earnings, matched by their respective employers, into the plan over the duration of their working life. Individuals typically receive their CPP/QPP benefit at age 65 , although one can opt to receive a smaller benefit at age 60 or wait to receive a larger one at age 70 (Government of Canada, 2020a, 2020b). Women tend, on average, to have lower CPP/QPP pensionable earnings relative to men given the emergence of various disruptions in their career trajectories (i.e., child rearing, caregiving) (Marier \& Skinner, 2008), and the propensity for them to occupy lower-waged jobs (Moyser, 2019; Young, 2011) or work fewer hours, often in part-time, seasonal or contract positions, or self-employment (Harding, 2018).

Public pensions have not kept pace with the rising cost of living, largely due to the indexation of public pension plans being tied to prices, not wages (Baldwin \& Shillington, 2017), and the depreciating values of these plans have a more dramatic impact on women. CPP replaces up to $25 \%$ of a Canadian worker's lifetime contributory earnings. A series of amendments passed between 1966 to 1987 extended provisions to allow for interruptions in women's labour market participation related to care and social reproduction responsibilities. Although some of women's work patterns are accounted for by sanctioning a limited drop-out provision in which contributors are able to exclude up to $17 \%$ of months of low or nil income over their working life, this provision is decidedly insufficient for those providing care for family members over more protracted periods of their lives. Moreover, as women typically make less money in wages than men, they receive considerably less in CPP at retirement (Young, 2011). Not all women receive CPP (96\% of men over age 65 received CPP in 2013 relative to $86 \%$ of women), according to Shilton (2013), and women's benefits are lower on average, at roughly $80 \%$ of men's. Earlier estimates suggest that by 2050 women will continue to receive only $80 \%$ of the pension received by men (Canada, Parliament, Senate, 2009). For those making upwards of the median household income in Canada (which was $\$ 61,400$ in 2018; Statistics Canada, 2020a), there remains a cap on CPP contributions (i.e., in 2020, the maximum annual pensionable earnings was $\$ 58,700$; Government of Canada, 2020b). As such, CPP contributors are limited in how much they can contribute to this pension plan over their working life and are thus encouraged to save for retirement through other retirement savings mechanisms, namely private plans (Young, 2011).

The retirement income system's third pillar includes employer pension plans and private savings plans. The latter are encouraged through specific programs that reward those able to set aside money for the future through, for example, Registered Retirement Savings Plans (RRSPs) and/or Tax-free Savings Accounts (TFSAs). As women earn less employment income than men, their ability to invest in private savings plans is often compromised. Occupational pension plans (such as RRSPs) typically reside in the public sector, as more than $75 \%$ of individuals employed in the private sector lack such coverage (Marier, 2010). Although women are just as likely to be found in unionized environments as men (Card et al., 2020), occupational pension plans typically involve earnings contributions by employees, with many employers adding to or even matching these contributions, which advantages those-typically males-with higher wages (Drolet \& Morissette, 2014).

As noted, there is a dearth of literature on the gender pension gap across the various pension vehicles in Canada. What we do know is that women, relative to men, tend to be overrepresented for provisions available under pillar one (i.e., particularly the GIS), while they remain under-represented or receive less in benefits under pillar two (i.e., CPP/QPP), and collect fewer gains under pillar three (i.e., in 2013 women's income was only $66 \%$ of that of men's in employment pensions and RRSPs) (Shilton, 2013). Statistics Canada data show women's contributions to RRSPs was about $69 \%$ of the median annual contribution for men in 2008, which Shilton (2013) argues is "very likely similar" for employment pension plans ( $p$. 111 ), representing $\$ 2,240$ and $\$ 3,220$ respectively. To be clear, the data described above outline women's average standing relative to men; not all women are disadvantaged in their wage and pensionable earnings. Those in academic fields in which women are under-represented or are in high demand (e.g., science, engineering, mathematics) may be able to command higher salaries, while those in sectors in which women are overrepresented (e.g., health, fine and applied arts, humanities) are typically offered less (Doucet et al., 2008). Women in professions yielding higher incomes are less vulnerable to the deleterious effects of insufficient income and pen- 
sion provisions. In the current work, using a case study, we simulate the long-term effects of the gender pay gap across different academic career trajectories leading to quantification of both the cumulative gender pay gap and resulting gender pension gap.

\section{Method}

\section{Case Study Context}

As our case study, we selected King's University College (hereafter "King's"), a small liberal arts college at Western University in southwest Ontario, Canada. King's is well suited as a case study because it provides a tractable model for calculating the gender wage and pension gap, given the few variables used to determine salary and pension, limited decision points for bias and discrimination to enter salary calculations, and a defined-benefit pension plan. The members of only 12 out of the 31 faculty associations (or 39\%) in the Ontario Council of University Faculty Associations (OCUFA) currently have defined-benefit pension plans (OCUFA Collective Bargaining Researcher, personal communication, December 14, 2020).

Doucet et al. (2008) describe the various ways pay anomalies become embedded in academic pay structures, often involving some configuration of the following factors: (a) pay at the point of hire; (b) seniority, based on a pay scale formulation documenting years of experience; (c) promotion through the ranks; (d) merit increases based on judgements of performance; (e) stipends rendered for the uptake of administrative responsibilities; and (f) market supplements offered to either attract or retain faculty (p. 69). Although pay adjustments based on years in rank are generally fixed, the other avenues described allow for considerable discretion, opening the door further to gender disparities. For example, a survey of faculty in tenure-track positions in eight Canadian universities found that racialized and female faculty were less likely to have received promotion to the rank of associate professor and tenure than non-racialized and non-female faculty, and the differences were statistically significant (Wijesingha \& Ramos, 2017, p. 61). An Ontario study of 933 promotions from associate to full professor in the 2010-2014 period found "a large gender gap in academic promotions favouring men" (Millar \& Barker, 2020, p. 47). Gender inequality in incidence and timing of promotion is reflected in gender inequality in pay over an academic career. An examination of the gender pay gap at a large Canadian research university found that use of market supplements to attract and retain faculty, and implementation of the Canada Research Chairs program-both involving discretionary judgements-favoured men academics, who were much more likely than women to benefit from these enhancements to their salaries (Doucet et al., 2012).

It should be noted that the salary determinations at other universities (often revisited at multiple time points across an individual's career), which include additional variables involving judgements of merit, are not captured in our case study. King's does not provide, at least at present, market supplements to attract or retain faculty, or merit pay in recognition of excellence in professors' teaching, research contributions, or service work. As a result, only starting salary, years of experience, and promotion influence the salaries of faculty members at King's, making salary calculations over the course of a career possible (with assumptions about future salary increases).

King's is home to a total of 99 full-time faculty members instructing 3,296 full-time undergraduate, 443 parttime undergraduate, and 61 graduate students (Universities Canada, 2020). Full-time faculty unionized in 2020 (Bangarth, 2020) and, through collective bargaining, the college has committed to a pay anomaly study with a fixed budget to address corrections. As increases to salary for faculty members are equal at King's, subject only to differences within ranks, any systemic discrimination that fuels gender wage disparities at the college would be introduced in (1) the determination of starting salary, specifically in the assignment of years of experience at time of hire; and/or (2) differential promotion rates for men and women. The determination of starting salary is to be based on teaching experience and, to a lesser degree, research and professional experience. The contribution of different factors to the years of experience used to determine starting salaries is outlined in the Policy on the Employment Status and Salary Level of New Faculty (King's University College, n.d.). Once hired, years of service are not negatively impacted by pregnancy, parental, or adoption leaves (King's University College, 2020), eliminating a possible means of systemic discrimination.

Examining the case of the gender-based salary and pension gap at King's offers certain comparative advan- 
tages. As in other Canadian universities, at King's there is a gender gap in starting salary, a gender difference in the likelihood of promotion from associate professor to full professor, and a codified set of terms and conditions concerning determination of salary, pension contribution, and progress through the ranks, typically contained in collective agreements or administrative decisions. However, King's is different from other Canadian universities in that salary increments over a career at King's are fixed and not based on judgements about merit, administrative contributions, or market supplements-decisions often tainted by gender bias, as noted earlier. From the perspective of methodology and theory, the King's case can be viewed as a conservative example of the accumulation of advantage for men and disadvantage for women due to systemic gender discrimination over time.

If we use Statistics Canada (2021) data to compare King's with 19 other Ontario universities in 2019-2020, we find that King's is close to the median in the distribution of salaries of full-time faculty at the rank of assistant professor: the median for 20 Ontario universities is $\$ 111,725$, while the median for King's is $\$ 108,400$. For the 20 Ontario universities, the median salary for all full-time men faculty was $\$ 158,886$, while the median for women was $\$ 146,762$. In comparison, the median for men faculty at King's was $\$ 135,550$, and $\$ 127,700$ for women faculty, respectively. While women faculty at the 20 Ontario universities earned $92.4 \%$ of their male colleagues' median salaries, the comparative figure for King's was $94.2 \%$. We are not arguing that King's is representative of the population of Ontario universities. However, the King's case illustrates the magnitude of the gender gap in lifetime and pension earnings among university faculty starting from a median salary at the assistant professor rank that is close to the median of the 20 Ontario universities. If systemic gender bias in decisions about starting salary and promotion have strong influence on lifetime earnings and pensions, as seen in the King's case, this suggests an even larger cumulative disadvantage for women in other universities due to potentially biased decision making about salary increments over one's career based on judgements of merit, market value, and administrative contributions.

\section{Calculation of Wage and Pension Gap}

The goal of the current work was to quantify the longterm impact of the gender wage gap on both salary and pension using the information, assumptions, controls, and formulae detailed below. Rather than examining individual faculty salaries and trajectories, we simulated the impact of observed gender differences in salary across different plausible career trajectories: Scenario A, where neither the woman nor man is promoted to full professor; Scenario B, where both the woman and man are promoted to full professor; and Scenario $\mathrm{C}$, where the woman remains an associate professor while the man is promoted to full professor. Scenario $C$ reflects that women are considerably less likely to become full professors than men; less than three in 10 full professors in Ontario (Statistics Canada, 2019a), and four in 12 full professors at King's, are women (compared to 36 out of 64 associate professors and 11 out of 23 assistant professors at King's). Overall, this methodology allows us to see the impact of differences in starting salaries and promotion rates on the gender wage and pension gap across career trajectories while controlling for individual differences.

We took as our starting point that women faculty at King's make, on average, $91 \%$ of the salary of men (Statistics Canada, 2020b). As noted in the context, given the existing pay structure, a primary source of pay inequity would be the subjective, and potentially biased (Wiedman, 2019), determination of years of experience at hiring. Thus, the salary gap was modelled via a difference in the subjective determination of years of experience granted at the time of hire, a difference of 3.5 years, resulting in women starting at $91.3 \%$ of the salary of men. This gap is consistent with both the Statistics Canada (2020b) and OCUFA (2016) data.

We made the assumption of a $1 \%$ increase to salary and progression through the ranks per year (as per the current terms and conditions; King's University College, 2020). We imposed the following controls: promotion to associate professor after six years (based on King's University College, 2020); career length of 30 years, age at retirement of 65 years; and overall life expectancy of 86.1 years (based on the life expectancy of Ontarians at age 65; Statistics Canada, 2020c). Current formulae for annual salary (Equation 1; King's University College, 2020) and pension calculations (Equation 2; King's University College, 2017) are outlined below. All calculations 
were performed using MATLAB (Version 2020a); the code appears in the Appendix.

Annual salary $=$ base salary + (years of experience $x$ progression through the ranks)

Where base salary is the same for all faculty $(\$ 89,430)$, years of experience is negotiated on an individual basis at hiring and increments each year, and progression through the ranks is determined by rank ( $\$ 2,506$ assistant, $\$ 2,637$ associate, $\$ 2,770$ full). Promotion to full professor increases years of experience by one.

Annual pension $=(2 \% \mathrm{x}$ final average earnings $) \mathrm{x}$ years of service

Where final average earnings = individual's highest average three-year annual salary, modelled as the last three years of employment for the current article.

\section{Results}

To quantify the long-term impact of the gender wage gap, we calculated the cumulative effect of a gender wage gap in starting salaries of $\$ 8,771$ (women making $91.3 \%$ of the salary of their male colleagues) on both salary and pension across the course of a 30-year career and 21-year retirement by simulating three different career trajectory scenarios. The results of these simulations are shown in Table 1. Given the methodology used of directly calculating the results of different assumptions and scenarios (using Equation 1 and Equation 2), no further statistical analysis is appropriate.

\section{Scenario A}

In Scenario A, both the woman and man are promoted to associate professor after six years at the assistant professor level and end their careers as associate professors. For faculty who top out at the rank of associate professor, this discrepancy in starting salary of $\$ 8,771$ would result in a $\$ 305,894$ difference in salary across a career and a further $\$ 147,763$ difference in pension, for an overall discrepancy of $\$ 453,657$. In retirement, this would reflect a $\$ 7,003$ difference annually in pension income. Thus, $32 \%$ of the gender wage and pension gap in this scenario is due to discrepancies in pension.

\section{Scenario B}

In Scenario B, both the woman and man are promoted to full professor after 12 years at the associate professor level. For faculty who achieve the rank of full professor, this same discrepancy in starting salary would result in a $\$ 312,826$ difference in salary across a career and a further $\$ 155,148$ difference in pension, for an overall discrepancy of $\$ 467,974$. In retirement, this would reflect a $\$ 7,353$ difference annually in pension income. In this scenario, $33 \%$ of the gender wage and pension gap is due to discrepancies in pension. This conservative estimate assumes that women achieve the rank of full professor at the same point as men.

The assumption of 12 years at the rank of associate professor before promotion to full professor was made based on the difference in median age of full-time faculty in Ontario at different ranks (Statistics Canada, 2019b). We took the difference of the median age of full professors and assistant professors ( $M=18$ years) and subtracted the six years at assistant professor (see scenario controls) to arrive at this value (i.e., 12 years) for the length of time at associate level before promotion to full professor. Reducing this value increases the gender pay gap but has no impact on the pension gap in our simulations within the context of this case study.

\section{Scenario C}

In Scenario C, the woman is promoted to associate professor after six years at the assistant professor level and ends her career as an associate professor (i.e., Scenario A); whereas the man is promoted to full professor after 12 years at the associate professor level (i.e., Scenario B). Modelling this more common situation, where men achieve the rank of full professor while their women colleagues do not, leads to a $\$ 401,187$ difference in salary across a career and a further $\$ 258,601$ difference in pension, for an overall discrepancy of $\$ 659,788$. In retirement, this would reflect a $\$ 12,256$ difference annually in pension income. Thus, $39 \%$ of the gender wage and pension gap in this scenario is due to discrepancies in pension.

\section{Summary}

Our calculations revealed that the long-term impact of the gender wage and pension gap for women professors 
Table 1

Cumulative effects (\$) of the gender pay gap in starting salary on both salary and pension across different career-trajectory scenarios

\begin{tabular}{|c|c|c|c|c|c|c|c|c|c|}
\hline \multirow[t]{2}{*}{ Scenario } & \multicolumn{3}{|c|}{ Cumulative Salary } & \multicolumn{3}{|c|}{ Cumulative Pension } & \multicolumn{3}{|c|}{ Total (Salary + Pension) } \\
\hline & Man & Woman & Gap & Man & Woman & Gap & Man & Woman & Gap \\
\hline$A$ & $\$ 4,678,985$ & $\$ 4,373,091$ & $\$ 305,894$ & $\$ 2,761,990$ & $\$ 2,614,227$ & $\$ 147,763$ & $\$ 7,440,975$ & $\$ 6,987,318$ & $\$ 453,657$ \\
\hline B & $\$ 477,4278$ & $\$ 4,461,452$ & $\$ 312,826$ & $\$ 2,872,828$ & $\$ 2,717,680$ & $\$ 155,148$ & $\$ 7,647,106$ & $\$ 7,179,132$ & $\$ 467,974$ \\
\hline C & $\$ 4,774,278$ & $\$ 4,373,091$ & $\$ 401,187$ & $\$ 2,872,828$ & $\$ 2,614,227$ & $\$ 258,601$ & $\$ 7,647,106$ & $\$ 6,987,318$ & $\$ 659,788$ \\
\hline
\end{tabular}

Note: Scenario $A=$ both associate professors; Scenario $B=$ both full professors; Scenario $\mathrm{C}=$ man is full professor, woman is associate professor.

at the college is in the vicinity of half a million dollars, with a third of the overall gender gap due to discrepancies in pension. Our case study provides a conservative estimate of the gender wage and pension gap; Statistics Canada indicates that the gender wage gap in Ontario is higher (with women professors earning $90 \%$ of men's salaries) (2020b) and the gender wage gap is greater for non-unionized faculty (OCUFA, 2016), which would in turn lead to a larger gender pension gap. These discrepancies in pension have generally not been reported in studies of the gender wage gap. Under a defined-benefit pension plan, like the one in our case study, even though women could potentially accrue more cumulative pension (under certain scenarios) by living longer than men, they have a considerably lower annual income in retirement ( $\$ 7,003-\$ 12,257$ lower in our scenarios), the future value of which diminishes over time.

\section{Discussion}

Canada has garnered accolades internationally for its pension system: a system that up until the 1990 s reflected a fairly high degree of egalitarianism. Discussions on pension reform in Canada over the last two decades have largely accentuated the role of private pensions and savings in making up individuals' retirement income. Given the stagnation of public retirement plan incomes, and the decreasing availability of employer-sponsored pension plans, private plans have become the main source of retirement income for many Canadians. The retirement landscape is changing, however, giving rise to questions not only about the sufficiency of public pensions (par- ticularly for those on low incomes), but about the ability of both women and men to contribute to privatized plans amidst ever-rising costs, particularly of housing. Although Canadian pension plans have been, and continue to be, strong vehicles for poverty alleviation (i.e., offering a guaranteed income for those in low-income), the increased emphasis on private plans has exacerbated retirement inequality. This trend particularly disadvantages women in the lowest income quintiles (Curtis \& McMullin, 2019).

As a result of their higher-than-average earnings over the course of their careers, women who are fulltime faculty members may not be subject to the disadvantage associated with reduced CPP and OAS benefits that women in other employment sectors may be privy to (i.e., some women professors may not receive full OAS benefits if their retirement incomes are high enough to be subject to the OAS clawback). They also are likely to have reached the maximum allowable in CPP pension contributions due to having incomes above the prescribed thresholds; although some may see reduced CPP pension earnings should they have exceeded the drop-out provision (generally associated with more protracted periods taken out of the workforce to care for children or family members). Given that women professors are less apt to benefit from public pension programs visà-vis other populations, their private and occupational pension benefits become all the more important to their retirement livelihoods.

On average, women live longer than men (in Canada, 84.1 vs. 79.9 years; Statistics Canada, 2020c) and, as such, they require more money in savings-or signif- 
icant benefits derived from public pensions or accrued in a robust occupational pension plan-to see them through their retirement years (Young, 2011). Although defined benefit pension plans (as reflected at the case study university) can provide recipients with a stable, uniform income over the course of their retirement years, the rapid pace at which the cost of living (and housing) has escalated over time (see Curtis \& McMullin, 2019) makes the suitability of these incomes in the future far less certain. As such, women's longevity relative to men's introduces another potential source of inequity, as their private savings must be made to stretch over a longer life span. Zaman (2017), in examining TFSA participation trends, found no bias in terms of gender, although the majority of tax-filing Canadians (close to 66\%) were not contributing to this program in 2013 , and those who did tended to be from households with higher net worth (higher after-tax income was not statistically significant, although age and education were). Families with dependent children participated and contributed less to this savings plan. Given that TFSAs are "less attractive on distributional grounds" (p. 331), the plan is, according to Zaman (2017), associated with a take-up "challenge similar to that of the RRSP" (p. 347). Private savings plans privilege those (usually men; Denton \& Boos, 2007) with the ability to accumulate savings over the duration of their working life (Curtis \& McMullin, 2019), which may not always be the case for those entering the workforce later in life (i.e., those taking a significant number of years to obtain the education necessary for an academic career) (Lin, 2008), or those who are saddled with the significant financial burdens of raising children (Agopsowicz, 2019). We know that women typically have less capacity to build the wealth necessary to substantially invest in private savings plans, including RRSPs and TFSAs (Marier \& Skinner, 2008), although it remains unclear the extent to which this applies to women in the professoriate in Canada.

In 2019, women in academia in Canada made, on average, $\$ 10,500$ less than their male counterparts (as calculated from data from Statistics Canada, 2020b), providing them less money each year to accrue funds in private savings plans relative to men, and fewer earnings to contribute monthly to occupational pension plans. Furthermore, an analysis of Ontario data for 1996-2016 found that men in the professoriate are more likely than women to be promoted, and the pay gap increases as women faculty members move up the ranks (Momani et al., 2019). In our analysis of data from King's, beginning with a $\$ 8,771$ difference in starting pay (less than the average identified by Statistics Canada [2020b]), we calculated the long-term effects of the gender wage and pension gaps by simulating three different career scenarios: (1) women and men faculty topping out at the rank of associate professor, (2) women and men faculty both achieving the rank of full professor, and (3) the more typical scenario of men achieving the rank of full professor while women faculty top out at the rank of associate professor. We found that this starting wage gap alone resulted in a $\$ 306,000$ to $\$ 401,000$ gender wage gap over the course of a career, and a further $\$ 148,000$ to $\$ 259,000$ gender pension gap in the college's defined benefit plan, for a total gender pension and wage gap of $\$ 454,000$ to $\$ 660,000$.

Given the disparities noted heretofore, the public pension profile for women professors is anticipated to include: little to no benefits through OAS, and the maximum benefit accrued in CPP (currently, $\$ 1,175.83$ per month; Government of Canada, 2020a). For private plans, they may have some retirement savings (i.e., RRSPs, TFSAs), although likely less than what men might acquire given their higher overall salaries, and their occupational plan, which would provide less than what men in the same rank would expect to receive. The latter could translate into a difference of almost a quarter of a million dollars. As we can see from our analysis, the occupational benefit plan at the college is exceedingly sensitive to the systemic discrimination typically imposed at the beginning of women's careers in the determination of starting salary, an inequity that widens over the scope of their working life. This inequity is higher still as women move up the ranks (i.e., the gap is widest at the level of full professor).

The gender pay gap in academia has been identified and quantified (CAUT, 2018; OCUFA, 2016). Though previous reports have noted that the long-term effects of the gender gap are no doubt greater (OCUFA, 2016), due to the effect of income on pension, the gender pension gap has not been similarly quantified. Apart from starting salary alone, King's has few junctures in which systemic discrimination can be introduced into its pay structure, making most other universities that do calculate salary increments for merit or administrative service even more susceptible to overall gender pay inequities. In our simu- 
lations of the long-term impact of the gender pay gap, we identified that the gender pension gap is in the range of $\$ 150,000$ to $\$ 250,000$ cumulatively ( $\$ 7,000$ to $\$ 12,250$ annually), constituting an additional $48-64 \%$ on top of the gender pay gap. Thus, previous work has substantially underestimated the long-term effects of the existing gender pay gap within, and outside of, academia.

\section{Author Note}

Tracy Smith-Carrier and Marcie Penner contributed equally to the work. All authors indicate that we have no conflicts of interest to disclose.

\section{References}

Agopsowicz, A. (2019). Family matters: The cost of having children on women's careers. RBC Economic Research. http://www.rbc.com/economics/ economic-reports/pdf/other-reports/FamilyMatters. pdf? ga $=2.10553716 .1905560730 .1583159630-$ 1036793344.1550167236

Baldwin, B., \& Shillington, R. (2017). Unfinished business: Pension reform in Canada. Institute for Research on Public Policy Study. https://irpp.org/ research-studies/unfinished-business-pension-reform-in-canadal

Bangarth, S. (2020). Courage, strength, and resolve: How the King's University College Faculty Association unionized in the middle of a pandemic. Academic Matters. https://academicmatters.cal courage-strength-and-resolve-how-the-kings-university-college-faculty-association-unionized-in-themiddle-of-a-pandemicl

Canada, Parliament, Senate. Standing Committee on the Status of Women. (2009). Pension security for women. 40th Parl., 2nd sess. Rept. 9. https://www. ourcommons.ca/DocumentViewer/en/40-2/FEWO/ report-9/

Canadian Association of University Teachers. (2018). Underrepresented \& underpaid: Diversity \& equity among Canada's post-secondary education teachers. https://www.caut.ca/sites/default/files/caut equity report 2018-04final.pdf

Card, D., Lemieux, T., \& Riddell, W. C. (2020). Unions and wage inequality: The roles of gender, skill and public sector employment. Canadian Journal of Economics/Revue canadienne d'économique, 53(1), 140-173. https://doi.org/10.1111/caje.12432

Currie, J., \& Hill, B. (2013). Gendered universities and the wage gap: Case study of a pay equity audit in an Australian university. Higher Education Policy, 26, 65-82. https://doi.org/10.1057/hep.2012.19

Curtis, J., \& McMullin, J. (2019). Dynamics of retirement income inequality in Canada, 1991-2011. Journal of Population Ageing, 12, 51-68. https://doi. org/10.1007/s12062-018-9219-5

Denton, M., \& Boos, L. (2007). The gender wealth gap: Structural and material constraints and implications for later life. Journal of Women \& Aging, 19(3-4), 105-120. https://doi.org/10.1300/J074v19n03 08

Doucet, C., Durand, C., \& Smith, M. R. (2008). Who gets market supplements? Gender differences within a large Canadian university. Canadian Journal of Higher Education, 38(1), 67-103. https://doi. org/10.47678/cjhe.v38i1.517

Doucet, C., Smith, M. R., \& Durand, C. (2012). Pay structure, female representation and the gender pay gap among university professors. Industrial Relations, 67(1), 51-75. https://doi. org/10.7202/1008195ar

Drolet, M., \& Morissette, R. (2014). New facts on pension coverage in Canada (Catalogue number 75-006-X). Statistics Canada. https://www150. statcan.gc.ca/n1/en/pub/75-006-X/2014001/article/14120-eng.pdf

Gatto, L., Heyko, D., Plesca, M., \& Antonie, L. (2018). Gender wage gap in the university sector: A case study of all universities in Ontario, Canada. In S. Staab, O. Koltsova, \& D. Ignatov (Eds.), SocInfo 2018: Social informatics (pp. 242-256). Lecture Notes in Computer Science series, Vol. 11185. Springer. https://doi.org/10.1007/978-3-030-01129$\underline{115}$

Gazso, A. (2005). The poverty of unattached senior women and the Canadian retirement income system: A matter of blame or contradiction. Journal of Sociology \& Social Welfare, 32(2), 41-62. 
https://link.gale.com/apps/doc/A133774837/ AONE? $u=l o n d 95336 \&$ sid $=A O N E \& x i d=14 d 90 \mathrm{~d} 45$

Government of Canada. (2020a). Canada Pension Plan: Pensions and benefits payment amounts. https:ll www.canada.ca/en/services/benefits/publicpensions/cpp/payment-amounts.html

Government of Canada. (2020b). Canada Revenue Agency announces maximum pensionable earnings for 2020. https://www.canada.ca/en/revenue-agency/news/newsroom/tax-tips/tax-tips-2019/cra-announces-maximum-pensionable-earnings-2020. $\underline{\mathrm{html}}$

Harding, A. (2018). The effect of government transfer programs on low-income rates: A gender-based analysis, 1995 to 2016 (Catalogue number 75F0002M). Statistics Canada. https://www150. statcan.gc.ca/n1/pub/75f0002m/75f0002m2018003eng.htm

King's University College. (n.d.). Policy on the employment status and salary level of new faculty. King's University College.

King's University College. (2017). Faculty pension and benefits discussion. https://www.kings.uwo.cal kings/assets/File/depts/finance/payroll/PensionPresentation.pdf

King's University College. (2020). Collective agreement between King's University College and King's University Faculty Association (KUCFA) May 1st, 2020 to April 30th, 2022. https://www.kings.uwo.ca/kings/ assets/File/extranet/hr/agreements/FacultyAgreement.pdf

Li, P. S. (2012). Differences in employment income of university professors. Canadian Ethnic Studies, 44(2), 39-48. https://doi.org/10.1353/ces.2012.0012

Lin, J. (2008). The teaching profession: Trends from 1999 to 2005 (Catalogue number 81-004-XIE). Statistics Canada. https://www150.statcan.gc.cal n1/pub/81-004-x/2006004/9540-eng.htm

Mang, C. F. (2019). Earnings differences among senior university administrators: Evidence by gender and academic field. Canadian Journal of Higher Education, 49(3), 24-40. https://doi. org/10.7202/1066633ar
Marier, P. (2010). Improving Canada's retirement saving: Lessons from abroad, ideas from home. Institute for Research on Public Policy Study. https:/l irpp.org/wp-content/uploads/assets/research/faces-of-aging/improving-canadas-retirement-saving/ IRPP-Study-no9.pdf

Marier, P., \& Skinner, S. (2008). The impact of gender and immigration on pension outcomes in Canada. Canadian Public Policy/Analyse de Politiques, 34, 59-78. http://www.jstor.org/stable/25463654

Millar, P., \& Barker, J. E. (2020). Gender and promotion to full professor in Ontario. Canadian Journal of Sociology, 45(1), 47-62. https://doi.org/10.29173/ cjs29365

Momani, B., Dreher, E., \& Williams, K. (2019). More than a pipeline problem: Evaluating the gender pay gap in Canadian academia from 1996 to 2016. The Canadian Journal of Higher Education, 49(1), 1-21. https://doi.org/10.47678/cjhe.v49i1.188197

Moyser, M. (2019). Measuring and analyzing the gender pay gap: A conceptual and methodological overview. Statistics Canada. https://www150.statcan. gc.ca/n1/pub/45-20-0002/452000022019001-eng. $\underline{\mathrm{htm}}$

Ontario Confederation of University Faculty Associations. (2016). Pay equity among faculty at Ontario universities: OCUFA's submission to the Ontario Gender Wage Gap Steering Committee. https:/l ocufa.on.ca/assets/OCUFA-Submission-on-theGender-Wage-Gap-FINAL.pdf

Pelletier, R., Patterson, M., \& Moyser, M. (2019). The gender wage in Canada: 1998 to 2018 (Catalogue Number 75-004-M - 2019004). Statistics Canada. https://www150.statcan.gc.ca/n1/pub/75-004-m/75004-m2019004-eng.htm

Pesando, J. E., Gunderson, M., \& McLaren, J. (1991). Pension benefits and male-female wage differentials. Canadian Journal of Economics, 24(3), 536-550. https://doi.org/10.2307/135578

Qian, Y., \& Fuller, S. (2020). COVID-19 and the gender employment gap among parents of young children. Canadian Public Policy, 46(S2), S89-S101. https:/l doi.org/10.3138/cpp.2020-077 
Shilton, E. (2013). Gender risk and employment pension plans in Canada. Canadian Labour \& Employment Law Journal, 17, 101-141. https://ssrn.com/ abstract $=2302820$

Shirle, T. (2019). Study of gender-based salary differentials at the University of Manitoba: Final report. http://umanitoba.ca/admin/human resources/equity/media/Schirle Final Report.pdf

Statistics Canada. (2021). Table: 37-10-0108-01 Number and salaries of full-time teaching staff at Canadian universities [Data table]. https://www150. statcan.gc.ca/t1/tbl1/en/tv.action?pid=3710010801

Statistics Canada. (2020a). Canadian Income Survey, 2018. https://www150.statcan.gc.ca/n1/daily-quotidien/200224/dq200224a-eng.htm

Statistics Canada. (2020b). Table: 37-10-0108-01 Number and salaries of full-time teaching staff at Canadian universities [Data table]. https://www150. statcan.gc.ca/t1/tbl1/en/tv.action?pid=3710010801

Statistics Canada. (2020c). Table: 13-10-0114-01 Life expectancy and other elements of the life table, Canada, all provinces except Prince Edward Island [Data table]. https://www150.statcan.gc.ca/t1/tbl1/ en/cv.action?pid=1310011401

Statistics Canada. (2019a). Table 37-10-0108-01 Number and salaries of full-time teaching staff at Canadian universities by median salary, rank and sex, for 20 Ontario universities (excluding medical and dental faculties) [Data table]. https://doi. org/10.25318/3710010801-eng

Statistics Canada. (2019b). Table 37-10-0077-01 Number and median age of full-time teaching staff at Canadian universities, by highest earned degree, staff functions, rank, sex [Data table]. https://doi. org/10.25318/3710007701-eng

Universities Canada. (2020). 2019 full-time and parttime fall enrolment at Canadian universities. https:ll www.univcan.ca/universities/facts-and-stats/enrolment-by-universityl

Wiedman, C. (2019). Rewarding collaborative research: Role congruity bias and the gender pay gap in academe. Journal of Business Ethics, 167(4), 793-807. https://doi.org/10.1007/s10551-019-04165-0
Wijesingha, R., \& Ramos, H. (2017). Human capital or cultural taxation: What accounts for differences in tenure and promotion of racialized and female faculty? Canadian Journal of Higher Education, 47(3), 54-75. https://doi.org/10.47678/cjhe.v47i3.187902

Young, C. (2011). Pensions, privatization, and poverty: The gendered impact. Canadian Journal of Women and the Law, 23(2), 661-685. https://doi. org/10.3138/cjwl.23.2.661

Zaman, A. A. (2017). Distributional impacts of Canada's tax-free savings accounts. Canadian Public Policy, 43(4), 331-349. https://doi.org/10.3138/cpp.2016$\underline{039}$

\section{Contact Information}

Marcie Penner

mpennerw@uwo.ca 